\title{
Effect of Systemic Inducing Resistance and Biostimulant Materials on Apple Scab Using a Detached Leaf Bioassay
}

\author{
Glynn C. Percival
}

\begin{abstract}
A detached leaf bioassay was used to evaluate several systemic inducing resistance agents, a range of biostimulant products and a conventional triazole fungicide (myclobutanil) on apple scab (Venturia inaequalis) development under laboratory conditions. None of the biostimulant products (seaweed extract, betaine, molasses, humic acid, yucca extract, and plant hormone/vitamin complex) evaluated in this study inhibited germination of apple scab conidia, subsequent formation of appressoria or reduced leaf scab severity compared to water treated controls. All SIR agents used in this investigation (potassium phosphonate, potassium phosphite, harpin protein, salicylic acid, salicylic acid derivative) inhibited germination of apple scab conidia, subsequent formation of appressoria and reduced leaf scab severity. The synthetic fungicide myclobutanil resulted in the greatest levels of germination inhibition, reduced appressorium development and leaf scab severity. Results suggest application of an appropriate SIR product may provide a useful addition to existing methods of apple scab management; however, use of biostimulants as scab protectant compounds appears limited. Key Words. Fungicides; Integrated Disease Management; Pathogen Control; Plant Health Care; Urban Landscapes.
\end{abstract}

Apple scab caused by Venturia inaequalis (Cooke) G. Wint., is one of the most serious diseases of ornamental and fruiting apples (MacHardy 1996). Presently, this disease is controlled mainly by synthetic fungicides applied frequently throughout the growing season (Holb et al. 2005). Identification of fungicide insensitive $V$. inaequalis isolates emphasise the need to evaluate nonfungicidal approaches to scab control (Stanis and Jones 1985; Schnabel and Parisi 1997). Genetically inherent constitutive and inducible defence responses protect trees against insect and pathogen attack (Krokene et al. 2008). Inducible resistance mechanisms such as systemic induced resistance (SIR) can be acquired by exposing plants to organic and/or synthetic compounds such as inorganic potassium and phosphate salts, compost water extracts, low molecular weight proteins, and unsaturated fatty acids (Percival 2001). Developments in plant protection technology have led to the commercial availability of a range of SIR products that have been shown to reduce disease severity in many economically important grasses, crops, and woody plants. These SIR products may offer a potential environmentally benign alternative to synthetic fungicides (Percival and Haynes 2008). These compounds have no direct action on pathogens and are generally of lower mammalian toxicity than synthetic fungicides. Inoculations with the pathogen following treatment with a SIR product fail to cause disease, or the degree of disease severity is reduced (Van Loon et al. 2006). Among the SIR elicitors, harpin protein (Messenger) benzothiadiazole (Bion), potassium phosphite (Agri-Fos), potassium phosphonate (Phytogard), salicyclic acid (DSP), salicylic acid analogs (Rigel), and Probanazole (Oryzemate ${ }^{\circledR}$ ), are wellknown and have shown to successfully reduce severity of fungal bacterial and viral diseases (Kato et al. 1984; Kessmann et al. 1994; Gorlach et al. 1996; Bécot et al. 2000; Bokshi et al. 2003).

Products sold as biostimulants differ from traditional N:P:K fertilizers in that their active ingredient consists of a range of or- ganic compounds such as plant hormones, humic acids, marine algae extracts, sea kelp, vitamins, and other chemicals that vary according to the manufacturer (Fraser and Percival 2003; Barnes and Percival 2006). Most manufacturers claim biostimulants possess wide activity against a broad range of pathogenic viral, bacterial, and fungal diseases and in addition enhance resistance to insect attack (Mandops 2009; Bio-Plex 2009; Maxicorp 2009). There are, however, few independent scientific studies to support these claims (Grubinger 2005; Portillo et al. 2007).

A laboratory based system for the rapid evaluation of resistance among apple genotypes and determining pathogenesis of $V$. inaequalis isolates was developed using a detached leaf bioassay (Yepes and Aldwinckle 1993a; Yepes and Aldwinckle 1993b). This detached leaf bioassay has been used to successfully evaluate the efficacy of several film forming polymers on apple scab development and suppression. Polymers displaying the greatest degree of scab suppression were carried forward for large scale field-testing, with the degree of scab control shown under field-testing reflecting those obtained under laboratory conditions (Percival and Boyle 2009). Consequently, studies to date indicate adoption of this detached leaf bioassay provides a means of identifying scab protectant properties that commercially available products may, or may not possess.

Aims of this study were to evaluate the efficacy of five SIR and seven biostimulant products against apple scab using a detached leaf bioassay under laboratory conditions.

\section{MATERIALS AND METHODS}

\section{Plant Material and Product Treatment}

The apple trial site consisted of a 0.75 ha ( 1.9 acres) block of apple (Malus $\times$ domestica cultivar (cv.) Golden Delicious inter- 
spersed with individual trees of Malus $\times$ domestica cv. Red Delicious and Gala as pollinators. Golden Delicious was chosen for experimental purposes due to its sensitivity to apple scab infection. Planting distances were based on $2 \mathrm{~m} \times 2 \mathrm{~m}(6.6 \mathrm{ft} \times 6.6 \mathrm{ft})$ spacing. The trees were planted in 2003 and trained under the central-leader system to an average height of $1.5 \mathrm{~m} \pm 0.15 \mathrm{~m}$ $(5 \mathrm{ft} \pm 0.5 \mathrm{ft})$, with mean trunk diameters of $10 \mathrm{~cm} \pm 1.2 \mathrm{~cm}(4$ in $\pm 0.5 \mathrm{in})$ at $45 \mathrm{~cm}$ (18 in) above the soil level. The trial site was located at the University of Reading Shinfield Experimental Site, University of Reading, Berkshire, UK $\left(51^{\circ} 43 \mathrm{~N},-1^{\circ} 08 \mathrm{~W}\right)$. The soil was a sandy loam containing $4 \%-6 \%$ organic matter, $\mathrm{pH}$ of 6.2 , available $\mathrm{P}, \mathrm{K}, \mathrm{Mg}, \mathrm{Na}$, and $\mathrm{Ca}$ were 52.0, 659.1, $175.2,49.4$, and $2188 \mathrm{mg}$ liter $(0.0001,0.005,0.002,0.0001$, $0.03 \mathrm{oz}$ per gallon), respectively. Five trees were sprayed until runoff with each product at two concentrations (Tables 1 and 2), 28 days after leaf flush (mid-May), a time when leaf material shows maximum photosynthetic performance (Kitao et al. 1998 ) with no visible symptoms of scab development. The lowest concentration used in Table 2 is based on manufacturer's recommended rate. Double concentration was also tested for each product. Spraying trees were left for 10 days to permit absorption and uptake of each product. By Day 10, twelve fully-expanded leaves per tree were excised from actively growing shoots and all leaf material was prepared within two hours of collection.

\section{Detached Leaf Protocol and Scab Evaluation}

Leaves were surface sterilized by immersing in $1 \%$ sodium hypochlorite for 30 seconds and then rinsed in sterile distilled water for one minute to remove sodium hypochlorite residues prior to drying on Whatman filter paper (Muhammed et al. 1996). Leaves were then placed abaxial surface down in plastic petridishes lined with moist (sterile distilled water) Whatman filter paper. Five plates with 12 detached leaves per plate (60 leaves per treatment) were inoculated by spraying with an axenic conidial suspension that included a mixture of races 1-5 of $\mathrm{V}$. inaequalis. The fungus was grown in wick cultures on $4 \%$ malt extract at $18^{\circ} \mathrm{C}\left(64^{\circ} \mathrm{F}\right)$ in the dark, and conidia were collected after washing each wick culture with $10 \mathrm{ml}(0.33 \mathrm{fl} \mathrm{oz})$ sterile distilled water, centrifuged (2000 g, $5 \mathrm{~min}$ ), and re-suspended in distilled water until a suspension of $10^{6}$ conidia $\mathrm{ml}(0.033 \mathrm{fl} \mathrm{oz})$ was obtained. After inoculation, all plates were sealed with a thin polythene film (Parafilm) permeable to air but not water and incubated in a growth chamber at $19^{\circ} \mathrm{C} \pm 1^{\circ} \mathrm{C}\left(66^{\circ} \mathrm{F} \pm 34^{\circ} \mathrm{F}\right), 16$ hours light/8 hours dark photoperiod from white fluorescent tubes at $40 \mu \mathrm{mol} \mathrm{m} \mathrm{m}^{2} \mathrm{~s}$ light intensity (Yepes and Aldwinckle 1993a).

At Day 5, post inoculation the percentage of conidia that had germinated and the percentage that had formed appressoria were determined on 100 spores from 20 leaves, 5 spores per leaf (Yepes and Aldwinckle 1993b). Leaves were decolorized overnight by immersing in $99 \%$ cold methanol and stained with periodic acid-basic fuchsin. Whole leaves were mounted on glass slides in glycerol and examined by light microscopy. The remaining forty leaves per treatment were assessed at Day 35 after inoculation using a leaf scab severity rating on the following scale: $0=$ No scab observed; $1=$ less than $5 \%$ of leaf area affected; $2=5 \%-20 \%$ of leaf area affected with some yellowing; 3 $=21 \%-50 \%$ of leaf area affected, significant leaf yellowing; $4=$ $51 \%-80 \%$ of leaf area leaves affected, severe leaf yellowing; $5=$ $81 \%-100 \%$ of leaf area with complete leaf yellowing. All laboratory experiments took place in 2007 and were repeated in 2008. Leaf scab severity ratings used in this study was based on UK and Ireland market standards for fungicide evaluation of scab control (Butt et al. 1990; Swait and Butt 1990). Scab severity ratings were undertaken by three independent BASIS (British Agrochemical Standards Inspection Scheme) qualified crop protection specialists based at Reading University in Reading, UK.

\section{Statistical Methods}

All data was analyzed using ANOVA and the differences between means were determined using Tukey $w$ procedure $(P=$ $0.05)$ using the Genstat for Windows program 8th Edition VSN International. Back transformed pathogen severity values are presented here to ease interpretation of these data. Likewise, an arcsine transformation was applied to percentage data before statistical analysis to ensure normality of data. The 2007 and 2008 data sets were not different when compared using a t-test, therefore, values presented represent pooled data for both years.

Table 1. Selected SIR and biostimulant products evaluated for the control of Venturia inaequalis on apple cv. Golden delicious under laboratory conditions.

\begin{tabular}{llll}
\hline Product & Active Ingredient & Property & Supplier \\
\hline Water (control) & - & - & - \\
PhytoGard & Potassium phosphonate & SIR & United Agri Products Ltd, Alconbury Weston, UK \\
Messenger & Harpin protein & SIR & EDEN Bioscience Corporation, N. Bothell, Washington, USA \\
Agri-Fos & Potassium phosphite & SIR & Orion Future Technology Ltd, Henwood House, Henwood, Ashford Kent, UK \\
DSP & Salicylic acid & SIR & Orion Future Technology Ltd, Henwood House, Henwood, Ashford Kent, UK \\
Rigel & Salicylic acid derivative & SIR & Orion Future Technology Ltd, Henwood House, Henwood, Ashford Kent, UK \\
Maxicrop Original & Seaweed extract & Biostimulant & Ciba Sp Maxicrop (UK) Ltd, P.O. Box 6027, Corby, UK \\
Resistim & Betaine & Biostimulant & Mandops UK Ltd, Eastleigh, Hampshire, UK \\
Bioplex 12-4-6. & Seaweed + humic acid extract & Biostimulant & United Agri Products Ltd, Alconbury Weston, UK \\
Fulcrum CRV & Molasses & Biostimulant & Banks Cargill Agriculture Ltd, St Hughs, Lincoln, UK \\
Redicrop & Natural plant compound & Biostimulant & United Agri Products Ltd, Alconbury Weston, UK \\
Crop Set & Yucca based material & Biostimulant & United Agri Products Ltd, Alconbury, Weston, UK \\
& with liquid fermentation products & & \\
Superthrive & Plant hormone/vitamin complex & Biostimulant & Urban Hydroponics, Unit 1, Back Lane, Bolton, UK \\
Systhane & Myclobutanil & Synthetic & Syngenta Crop Protection UK Ltd, Whittlesford, Cambridge, UK \\
& & fungicide & \\
\hline
\end{tabular}

SIR = Systemic Induced Resistance 
Table 2. Germination of conidiaz ${ }^{2}$, formation of appressoria ${ }^{y}$ and scab severity rating ${ }^{\mathrm{x}}$ on apple leaves of Malus $\times$ domestica cultivar Golden Delicious."

\begin{tabular}{|c|c|c|c|c|}
\hline Treatment & $\begin{array}{l}\text { Concentration per } \\
\text { litre }(0.26 \mathrm{gal})\end{array}$ & $\begin{array}{l}\text { Germination } \\
(\%) \text { at Day } 5\end{array}$ & $\begin{array}{l}\text { Conidia with } \\
\text { appressorium } \\
(\%) \text { at Day } 5\end{array}$ & $\begin{array}{l}\text { Leaf severity } \\
\text { rating at Day } 35\end{array}$ \\
\hline Water (control) & - & $93 \pm 11.0 \mathrm{ab}$ & $90 \pm 8.0 \mathrm{a}$ & $5.0 \pm 0.60 \mathrm{a}$ \\
\hline PhytoGard & $10 \mathrm{ml}(0.33 \mathrm{fl} \mathrm{oz})$ & $36 \pm 4.2 \mathrm{fg}$ & $44 \pm 4.7 \mathrm{e}$ & $2.0 \pm 0.20 \mathrm{ef}$ \\
\hline Messenger & $3.2 \mathrm{~g}(0.14 \mathrm{oz})$ & $68 \pm 7.3 \mathrm{bcde}$ & $77 \pm 8.5 \mathrm{abc}$ & $3.2 \pm 0.36 \mathrm{~cd}$ \\
\hline Messenger & $6.4 \mathrm{~g}(0.28 \mathrm{oz})$ & $58 \pm 5.3 \mathrm{de}$ & $50 \pm 4.7 \mathrm{de}$ & $2.4 \pm 0.30 \mathrm{def}$ \\
\hline Agri-Fos & $10 \mathrm{ml}(0.33 \mathrm{fl} \mathrm{oz})$ & $49 \pm 4.1 \mathrm{ef}$ & $70 \pm 8.0 \mathrm{abc}$ & $3.0 \pm 0.26 \mathrm{~cd}$ \\
\hline DSP & $3.0 \mathrm{ml}(0.10 \mathrm{fl} \mathrm{oz})$ & $46 \pm 5.0 \mathrm{ef}$ & $58 \pm 4.9 \mathrm{cde}$ & $2.3 \pm 0.30 \mathrm{ef}$ \\
\hline DSP & $6.0 \mathrm{ml}(0.20 \mathrm{fl} \mathrm{oz})$ & $40 \pm 5.0 \mathrm{fg}$ & $63 \pm 5.5 \mathrm{bcd}$ & $2.2 \pm 0.38 \mathrm{ef}$ \\
\hline Rigel & $3.0 \mathrm{ml}(0.10 \mathrm{fl} \mathrm{oz})$ & $60 \pm 6.1 \mathrm{cde}$ & 73土5.0abcd & $3.3 \pm 0.42 \mathrm{bcd}$ \\
\hline Rigel & $6.0 \mathrm{ml}(0.20 \mathrm{fl} \mathrm{oz})$ & $55 \pm 5.9 \mathrm{de}$ & $60 \pm 6.1 \mathrm{~cd}$ & $3.0 \pm 0.38$ \\
\hline Maxicrop Original & $10 \mathrm{ml}(0.33 \mathrm{fl} \mathrm{oz})$ & $90 \pm 12.0 \mathrm{ab}$ & $91 \pm 10.2 \mathrm{a}$ & $4.8 \pm 0.52 \mathrm{ab}$ \\
\hline Maxicrop Original & $20 \mathrm{ml}(0.66 \mathrm{fl} \mathrm{oz})$ & $94 \pm 10.4 \mathrm{ab}$ & $92 \pm 9.7 \mathrm{a}$ & $5.0 \pm 0.55 \mathrm{a}$ \\
\hline Resistim & $10 \mathrm{ml}(0.33 \mathrm{fl} \mathrm{oz})$ & $88 \pm 9.8 \mathrm{a}$ & $90 \pm 7.6 \mathrm{a}$ & $4.9 \pm 0.48 \mathrm{a}$ \\
\hline Resistim & $20 \mathrm{ml}(0.66 \mathrm{fl} \mathrm{oz})$ & $92 \pm 13.1 \mathrm{ab}$ & $90 \pm 8.0 \mathrm{a}$ & $5.0 \pm 0.57 \mathrm{a}$ \\
\hline Fulcrum CRV & $10 \mathrm{ml}(0.33 \mathrm{fl} \mathrm{oz})$ & $96 \pm 13.4 \mathrm{a}$ & $93 \pm 10.7 \mathrm{a}$ & $5.0 \pm 0.60 \mathrm{a}$ \\
\hline Fulcrum CRV & $20 \mathrm{ml}(0.66 \mathrm{fl} \mathrm{oz})$ & $94 \pm 12.1 \mathrm{ab}$ & $90 \pm 9.0 \mathrm{a}$ & $4.9 \pm 0.55 \mathrm{a}$ \\
\hline Redicrop & $10 \mathrm{ml}(0.33 \mathrm{fl} \mathrm{oz})$ & $88 \pm 11.1 \mathrm{ab}$ & $86 \pm 9.9 a$ & $5.0 \pm 0.61 \mathrm{a}$ \\
\hline Redicrop & $20 \mathrm{ml}(0.66 \mathrm{fl} \mathrm{oz})$ & $92 \pm 12.5 \mathrm{ab}$ & $90 \pm 9.0 \mathrm{a}$ & $5.0 \pm 0.60 \mathrm{a}$ \\
\hline Crop Set & $10 \mathrm{ml}(0.33 \mathrm{fl} \mathrm{oz})$ & $95 \pm 14.5 \mathrm{a}$ & $93 \pm 10.2 \mathrm{a}$ & $5.0 \pm 0.63 \mathrm{a}$ \\
\hline Crop Set & $20 \mathrm{ml}(0.66 \mathrm{fl} \mathrm{oz})$ & $93 \pm 11.0 \mathrm{ab}$ & $90 \pm 8.7 \mathrm{a}$ & $5.0 \pm 0.62 \mathrm{a}$ \\
\hline Superthrive & $0.25 \mathrm{ml}(0.008 \mathrm{fl} \mathrm{oz})$ & $80 \pm 8.9 \mathrm{abc}$ & $81 \pm 8.3 \mathrm{ab}$ & $4.4 \pm 0.44 \mathrm{ab}$ \\
\hline Superthrive & $0.50 \mathrm{ml}(0.16 \mathrm{fl} \mathrm{oz})$ & $77 \pm 8.0 \mathrm{abcd}$ & $80 \pm 8.0 \mathrm{abc}$ & $4.0 \pm 0.39 \mathrm{abc}$ \\
\hline Systhane & $0.3 \mathrm{ml}(0.01 \mathrm{fl} \mathrm{oz})$ & $27 \pm 2.6 f g$ & $35 \pm 4.2 \mathrm{e}$ & $1.3 \pm 0.21 \mathrm{ef}$ \\
\hline Systhane & $0.6 \mathrm{ml}(0.02 \mathrm{fl} \mathrm{oz})$ & $15 \pm 1.7 \mathrm{~g}$ & $31 \pm 4.0 \mathrm{e}$ & $1.0 \pm 0.16 \mathrm{f}$ \\
\hline
\end{tabular}

${ }^{\mathrm{z}}$ As $\%$ of spores.

${ }^{y}$ As $\%$ of germinated spores.

${ }^{x}$ Detached leaf scab severity index: scale $0=$ No scab observed; $1=$ less than $5 \%$ of leaf area affected; $2=5 \%-20 \%$ of leaf area affected with some yellowing; $3=21 \%-50 \%$ of leaf area affected, significant leaf yellowing; $4=51 \%-80 \%$ of leaf area leaves affected, severe leaf yellowing; $5=81 \%-100 \%$ of leaf area with complete leaf yellowing. ${ }^{w}$ Data represents pooled mean of 2007 and 2008 studies except Rigel and Superthrive that were evaluated in 2008 only. Mean \pm standard deviation of 80 leaves (germination of conidia, formation of appressoria) and 160 leaves scab severity rating. Lower case letters indicate significant differences between means for each evaluation date by Tukey highly significance test $(P=0.05)$. The lowest concentration used in Table 2 is based on manufacturer's recommended rate (single strength). The other concentration tested represents a double strength product application.

\section{RESULTS AND DISCUSSION}

Irrespective of concentration applied, none of the biostimulants products (Maxicrop Original, Resistim, Bioplex 12-4-6, Fulcrum CV, Redicrop, Crop Set, Superthrive) evaluated in this study inhibited germination of apple scab conidia, subsequent formation of appressoria or reduced leaf scab severity. In all cases, values recorded were statistically comparable with water based controls (Table 2). In support of this, Portillo et al. (2007) found little efficacy of a range of biostimulant active ingredients when evaluated in vitro against Phytophthora infestans of tomato. Likewise, data from field trials also seems to indicate little efficacy of products containing plant extracts against a range of pathogenic fungi (Grubinger 2005; Chalker-Scott 2005). However, research elsewhere indicated application of Yucca extracts provided control of apple scab comparable to sulphur using apple cv. Jonagold seedlings (Köhl 2006). Despite the apparent robustness of the detached leaf bioassay system used in this study (Yepes and Aldwinckle 1993a; Yepes and Aldwinckle 1993b; Percival and Boyle 2009), it should be emphasized results were obtained under laboratory conditions and may fluctuate from those obtained at the whole plant level.

All SIR agents used in this investigation (potassium phosphonate, potassium phosphite, harpin protein, salicylic acid, salicylic acid derivative) inhibited germination of apple scab conidia by $27 \%$ to $61 \%$, subsequent formation of appressoria by $14 \%$ to
$51 \%$, and reduced leaf scab severity by $36 \%$ to $60 \%$. In virtually all cases, the higher concentration of SIR product applied the greater the degree of inhibition was recorded (Table 2). Of the SIR products tested, potassium phosphonate (PhytoGard) applied at $10 \mathrm{ml}$ per liter $(0.26 \mathrm{gal})$ was the most effective inhibitor of germination five days after inoculation and showed the greatest level of inhibition of appressorium development (Table 2). In addition, this product resulted in the lowest leaf scab severity. Of the SIR products tested, harpin protein (Messanger) at $3.2 \mathrm{~g}$ $(0.14 \mathrm{oz})$ per liter was the least effective inhibitor of germination and appressorium development and a salicylic acid derivative (Rigel) applied at $3.0 \mathrm{ml}(0.1 \mathrm{fl} \mathrm{oz})$ per liter least effective in reducing leaf scab severity (Table 2 ). With reduced sensitivity to sterol inhibiting fungicides in field isolates of Venturia inaequalis identified as early as the mid 1980s, a greater emphasis on alternative pathogen control strategies to extend the effective commercial life of current synthetic fungicides and reduce the risk of resistance development is now advocated (Stanis and Jones 1985; Schnabel and Parisi 1997). Results of this investigation indicated that, under laboratory conditions, all SIR products tested inhibited germination of apple scab conidia, subsequent formation of appressoria and scab severity. Similar effects caused by SIR elicitors on the physiological development of root and foliar diseases to include downy mildew (Peronospora parasitica), bar- 
ley powdery mildew (Blumeria graminis f. sp. hordei), cucumber powdery mildew (Sphaerotheca fuliginea), downy mildew (Bremia lactucae), rust (Puccinia sorghi) charcoal rot (Macrophomina phaseolina), have been shown elsewhere (Kessmann et al. 1994; Reuveni et al. 1994; Reuveni et al. 1995; Godard et al. 1999; Bécot et al. 2000; Pajot et al. 2001; Srivastava et al. 2001; Martinelli et al. 2007). These studies suggested the detrimental effects on fungal development were the result of several modes of action to include synthesis of $\beta-1,3$-glucanases, chitinases (Busam et al. 1997), cysteine-rich proteins, beta-(1,3)-glucanase and the PR-1 proteins (Anfoka and Buchenauer 1997) by leaf and root tissue in response to SIR elicitors. Other morphological and biochemical changes in SIR protected plants include a significantly faster lignification response, which corresponded with an increase in peroxidase activity (Ajilan and Potter 1992), an accumulation of fungi-toxic $\beta$-ionone derivatives (Wyatt and Kuc 1992), induction of lipoxygenase (Staub et al. 1992), antimicrobial fatty acid derivatives (Namai et al. 1993), phenylalanine ammonia-lysase, phytoalexins (Elliston et al. 1977) and hydroxyproline-rich glycoprotein (Raggi 1998). Within conifers inducible defense systems include secondary resin production, synthesis of new phenolics, traumatic resin duct formation and initiation of a wound periderm (Franceschi et al. 2000).

The synthetic fungicide myclobutanil applied at $0.6 \mathrm{ml}(0.02$ $\mathrm{fl} \mathrm{oz})$ per liter resulted in the greatest germination inhibition $(84 \%)$, reduced appressorium development $(67 \%)$ and leaf scab severity (80\%) recorded in this study (Table 2). Within the UK and Ireland, myclobutanil is fully approved for scab control of ornamental and fruiting apples, identified as possessing protective and curative action and anti-sporulation activity (Anonymous 2008). The antisporulant and fungicidal effectiveness of myclobutanil against scab under laboratory and field conditions has been confirmed by other workers when evaluating fungicides for UK and Ireland marketing purposes (Butt et al. 1990; Swait and Butt 1990). Previous research indicates most commercially available SIR agents are generally less effective and consistent than standard synthetic fungicides for foliar disease control (Agostini et al. 2003; Percival and Haynes 2008). Results of this study support these conclusions with myclobutanil proving to be the optimal treatment in terms of spore germination inhibition, reduced appressorium development and leaf scab severity.

In conclusion, significant reductions in scab severity recorded in this study do give credence to the potential of SIR products as an alternative or compliment to conventional fungicides. As SIR products have no direct effect on pathogens then they are not, at least in the UK, subject to the stringent legislative restrictions that relate to the use and application of conventional pesticides that act by chemical means. Likewise even though induced resistance products are not totally effective for scab control, they may be useful in an integrated program with standard fungicides. Use of biostimulants as scab protectant compounds, however, appears limited based on results of this study.

\section{LITERATURE CITED}

Agostini, J.P., P.M. Bushong, and L.W. Timmer. 2003. Glasshouse evaluation of products that induce host resistance for control of scab, melanose, and Alternaria brown spot of citrus. Plant Disease 87:69-75.

Ajilan, A.M., and D.A. Potter. 1992. Lack of effect of tobacco mosaic virus-induced systemic acquired resistance to anthropoid herbivores. Phytopathology 82:647-651.
Anfoka, G., and H. Buchenauer. 1997. Systemic acquired resistance in tomato against Phytophthora infestans by pre-inoculating with tobacco mosaic virus. Physiological and Molecular Plant Pathology 50:85-101.

Anonymous. 2008. The UK Pesticide Guide. British Crop Protection Council, Cabi Publishing, Oxon, UK.

Barnes, S., and G.C. Percival. 2006. The influence of biostimulants and water-retaining polymer root dips on survival and growth of newly transplanted bare-rooted silver birch and rowan. Journal of Environmental Horticulture 24:173-179.

Bécot, S., E. Pajot, D. Le Corre, C. Monot, and D. Silué. 2000. Phytog$\operatorname{ard}^{\circledR}\left(\mathrm{K}_{2} \mathrm{HPO}_{3}\right)$ induces localized resistance in cauliflower to downy mildew of crucifers. Crop Protection 19:417-425.

Bio-Plex Plant Survival Essentials. 2009. Pro-Tech ${ }^{\mathrm{TM}}$. <http://www.bioplex.com/protech.asp>

Bokshi, A.I., S.C. Morris, and B.J. Deverall. 2003. Effects of benzothiadiazole and acetylsalicylic acid on B-1,3-glucanase activity and disease resistance in potato. Plant Pathology 52:22-27.

Busam, G., H.H. Kassemeyer, and U. Matern. 1997. Differential expression of chitinases in Vitis vinifera L. responding to systemic acquired resistance activators or fungal challenge. Plant Physiology 115:10291038.

Butt, D.J., A.A.J. Swait, and J.D. Robinson. 1990. Evaluation of fungicides against apple powdery mildew and scab. Tests of Agrochemicals and Cultivars 11. Annals of Applied Biology (supplement) 116:34-35.

Chalker-Scott, L. 2005. The Myth of Compost Tea, Episode III. <http:// www.puyallup.wsu. edu/ Linda\%20Chalker-Scott/ Horticultural \%20Myths_files/ Myths/Compost\%20tea\%203rd\%20time.pdf>

Elliston, J., J. Kuc, E. Williams, and J. Raje. 1977. Relation of phytoalexin accumulation to local and systemic protection of bean against anthracnose. Phytopathology. 88:114-130.

Franceschi, V.R., P. Karokene, T. Krekling, and E. Christiansen. 2000. Phloem parenchyma cells are involved in local and distant defense responses to fungal inoculation or bark-beetle attack in Norway spruce (Pinaceae). American Journal of Botany 87:314-326.

Fraser, G.A, and G.C. Percival. 2003. The influence of biostimulants on growth and vitality of three urban tree species following transplanting. Arboricultural Journal. 27:43-57.

Godard, J.F., S. Ziadi, C. Monot, D. Le Corre, and D. Silué. 1999. Benzothiadiazole (BTH) induces resistance in cauliflower (Brassica oleracea var botrysis) to downy mildew of crucifers caused by Peronospora parasitica. Crop Protection 18:397-405.

Gorlach, J., S. Volrath, G. Knaufbeiter, G. Hengy, and U. Beckhove. 1996. Benzothiadiazole, a novel class of inducers of systemic acquired resistance, activates gene expression and disease resistance in wheat. Plant Cell 8:629-643.

Grubinger, V. 2005. Compost tea to suppress plant disease. Published June 2005. University of Vermont Extension. <http://www.uvm.edu/ vtvegandberry/factsheets/composttea.html>

Holb, I.J., B. Heijne, J.C.M. Withagen, J.M. Gall, and M.J. Jeger. 2005. Analysis of summer epidemic progress of apple scab in different apple production systems in the Netherlands and Hungary. Phytopathology 95:1001-1020.

Kitao, M., T.T. Lei, and T. Koike. 1998. Application of chlorophyll fluorescence to evaluate $\mathrm{Mn}$ tolerance of deciduous broad-leaved tree seedlings native to northern Japan. Tree Physiology 18:135-140.

Kato, T., Y. Yamaguchi, T. Harano, T. Yokayama, and Y. Uyehara. 1984. Unsaturated hydroxy fatty acids, the self defensive substance in rice plants against rice blast disease. Chemical Letters 12:409-412. 
Kessmann, H., T. Staub, C. Hofmann, T. Maetzke, J. Herzog, E. Ward, S. Uknes, and J. Ryals. 1994. Induction of systemic acquired disease resistance in plants by chemicals. Annual Review of Phytopathology 32:439-459.

Köhl, J. 2006. Replacement of Copper Fungicides in Organic Production of Grapevine and Apple in Europe. <http://www.rep-co.nl/Documents/Publ\%20Executive\%20Summaries/REPCO-Period\%203\%20 Publishable\%20Executive\%20Summarypdf>

Krokene, P., N.E. Nagy, and H. Solheim. 2008. Methyl jasmonate and oxalic acid treatment of Norway spruce: anatomically based defense responses and increased resistance against fungal infection. Tree Physiology. 28:29-35.

MacHardy, W.E. 1996. Apple scab. Biology, epidemiology and management. St Paul, MN American Phytopathology Society.

Mandops. 2009. Resistim ${ }^{\circledast}$ : Plant nutrient supplement with biostimulants. $<\mathrm{http}: / / \mathrm{www} . \mathrm{mandops.co.uk/resistim.htm>}$

Martinelli, J.A., J.K.M. Brown, and M.S. Wolfe. 2007. Effects of barley genotype on induced resistance to powdery mildew. Plant Pathology 42:195-202.

Maxicorp USA, Inc. 2009. Benefits. <http://www.maxicrop.com/pages/ benefits.html>

Muhammed, Z., R.H. Brlansky, and L.W. Timmer. 1996. Infection of flower and vegetative tissues of citrus by Colletotrichum acutatum and C.gloeosporioides. Mycologia 88:121-128.

Namai, T., T. Kato, Y. Yamaguchi, and T. Hirukawa. 1993. Anti-rice blast activity and resistance induction of C-18 oxygenated fatty acids. Bioscience Biotechnology and Biochemistry 57:611-613.

Pajot E., D. LeCorre, and D. Silué. 2001. Phytogard ${ }^{\circledR}$ and DL- $\beta$-amino butyric acid (BABA) induce resistance to downy mildew (Bremia Lactucae) in Lettuce (Lactuca sativa L). European Journal of Plant Pathology 107:1573-8469.

Percival, G.C. 2001. Induction of systemic acquired disease resistance in plants: Potential implications for disease management in urban forestry. Journal of Arboriculture 27:181-193.

Percival, G.C., and I. Haynes. 2008. The influence of systemic inducing resistance chemicals for the control of oak powdery mildew (Microsphaera alphitoides) applied as a theraputic treatment. Arboriculture and Urban Forestry 34:191-200.

Percival, G.C., and S. Boyle. 2009. Evaluation of film forming polymers to control apple scab (Venturia inaequalis (Cooke) G. Wint.,) under laboratory and field conditions. Crop Protection 28:30-35.

Portillo, M., A. Collina, and A Brunelli. 2007. Activity of biostimulants towards Phytophthora infestans on tomato. Tenth Workshop of a European Network for development of an Integrated Control Strategy of potato late blight. Bologna (Italy), 2007.

Raggi, V. 1998. Hydroxyproline-rich glycoprotein accumulation in TMVinfected tobacco showing systemic acquired resistance to powdery mildew. Journal of Phytopathology 146:321-325.

Reuveni, M., V. Agapov, R. Reuveni. 1994. Foliar sprays of phosphates induces growth increase and systemic resistance to Puccinia sorghi in maize. Plant Pathology 43:245-250.
Reuveni, M., V. Agapov, R. Reuveni. 1995. Suppression of cucumber powdery mildew (Sphaerotheca fuliginea) by foliar sprays of phosphate and potassium salts. Plant Pathology 44:31-39.

Schnabel, G., and L. Parisi. 1997. Sensitivity of Venturia inaequalis to five DMI fungicides, including the new triazole fluquinconazole, and to pyrimethanil. Journal of Plant Disease Protection 104:36-46.

Srivastava, A.K., T. Singh, T.K. Jana, and D.K. Arora. 2001. Induced resistance and control of charcoal rot in Cicer arietinum (chickpea) by Pseudomonas fluorescens. Canadian Journal of Botany 79:787-795.

Stanis, V.F., and A.L. Jones. 1985. Reduced sensitivity to sterol inhibiting fungicides in field isolates of Venturia inaequalis. Phytopathology 75:1098-1101.

Staub, T., P. Ahl-Goy, and H. Kessmann. 1992. Chemically induced disease resistance in plants, pp. 239-249. In: Lyr, H., and C. Polter (Eds.). Proceedings 10th International Symposium of Systematic, Fungicidal and Antifungal Compounds. Eugen Ulmer, Stuttgart, Germany.

Swait, A.A.J., and D.J. Butt. 1990. Fungicides as antisporulants against apple powdery mildew and scab. Tests of Agrochemicals and Cultivars 11. Annals of Applied Biology (supplement) 116:36-37.

Van Loon, L.C., M. Rep, and C.M.J. Pieterse. 2006. Significance of inducible defense-related proteins in infected plants. Annual Review of Phytopathology 44:135-162.

Wyatt, S.E., and J. Kuc. 1992. The accumulation of $\beta$-ionine and 3 -hydroxy esters of $\beta$-ionine in tobacco immunised by foliar inoculation with tobacco mosaic virus. Phytopathology 82:580-582.

Yepes, L.M., and H.S. Aldwinckle. 1993a. Selection of resistance to Venturia inaequalis using detached leaves from in vitro-grown apple shoots. Plant Science 93:211-216.

Yepes, L.M., and H.S. Aldwinckle. 1993b. Pathogenesis of Venturia inaequalis on shoot-tip cultures and on greenhouse-grown apple cultivars. Phytopathology 11:1155-1164.

Acknowledgments. The authors are grateful for funding, in part, from the TREE FUND (Hyland Johns Grant).

\author{
Glynn C Percival \\ Plant Physiologist/Technical Support Specialist \\ R.A. Bartlett Tree Research Laboratory, Europe \\ The University of Reading \\ John Harborne Building, Whiteknights \\ Reading, RG6 6AU, United Kingdom \\ gpercival@bartlettuk.com
}


Résumé. Un bio-essais foliaire séparé a été utilisé pour évaluer un certain nombre d'agents pour induire une résistance systémique, soient une variété de bio-stimulants et un fongicide conventionnel de triazole (myclobutanil), contre le développement de la tavelure (Venturia inaequalis) sous des conditions de laboratoire. Aucun des bio-stimulants (extrait de plantes aquatiques, betaine, mélasses, acide humique, extrait de yucca, complexe hormonale/vitaminique) évalués dans cette étude n'a inhibé la germination des conidies de la tavelure, la formation subséquente des hyphes ou encore diminué la sévérité de la tavelure comparativement au groupe-témoin traité avec de l'eau. Tous les agents utilisés dans cette étude-phosphonate de potassium, phosphite de potassium, protéine harpine, acide salicylique, dérivé d'acide salicylique-ont inhibé la germination des conidies de la tavelure, la formation subséquente des hyphes et diminué la sévérité de la tavelure. Le fongicide synthétique myclobutanil a produit les meilleurs résultats quant à l'inhibition de la germination, la diminution de la formation des hyphes et la sévérité de la tavelure. Les résultats suggèrent que l'application d'agents appropriés peuvent constituer un complément utile aux méthodes existantes de gestion de la tavelure; cependant, l'utilisation de bio-stimulants comme agent protecteur face à la tavelure apparaît limitée.

Zusammenfassung. An Blättern wurde ein Biotest vorgenommen, um den Einfluss von verschiedenen systemischen Mitteln zur Erhöhung der Resistenz zu bewerten, eine Auswahl von Biostimulanz-Produkten und ein konventionelles Triazol-Fungizid bei der Entwickung von Apfelschorf-Entwicklung unter Laborbedingungen. Keins der BiostimulanzProdukte (Seetang-Extrakt, Betain, Molasse, Huminsäure, Yucca-Extrakt und Pflanzenhormon/Vitamin-Komplex), die in dieser Studie bewertet wurden, hemmten die Germination von Apfelschorf-Konidien, die subsequente Formation von Apressoria oder reduzierte die Schorfinfektion der Blätter, verglichen mit einer Kontrolluntersuchung, die nur mit Wasser behandelt wurde. Alle SIR-Agentien, die in dieser Studie verwendet wurden (Kaliumphosphonat, Kaliumphosphid, Harpin-Protein, Salicylsäure, Salicylsäure-Derivate) hemmten die Konidienbildung, die subsequente Appressoria-Bildung und reduzierten den Befall der Blätter. Die Ergebnisse verdeutlichen, daß die Applikation von dem richtigen SIR-Produkt eine nützliche Erweiterung der herkömmlichen Methoden zur Apfelschorf-Bekämpfung sein kann, während die Anwendung von Biostimulantien als Schutzstoff ein begrenztes Spektrum hat.

Resumen. Se usó un bioensayo foliar para evaluar la resistencia de varios agentes sistémicos, un rango de productos biolestimulantes y un fungicida convencional triazol (miclobutanil) en la costra foliar del manzano (Venturia inaequalis) desarrollado bajo condiciones de laboratorio. Ninguno de los productos bioestimulantes (extracto de algas, betaína, melaza, ácido húmico, extracto de yuca y complejo hormona/vitamina) evaluado en este estudio inhibió la germinación de las conidias de la costra, formación subsecuente de apresoria o reducida severidad de la costra, comparado a controles tratados con agua. El fungicida sintético miclobutanil dio los niveles de inhibición de la germinación más grandes, desarrollo reducido de apresurium y severidad de la costra foliar. Los resultados sugieren que la aplicación de un producto SIR apropiado puede proveer una adición útil para métodos existentes de manejo de la costra foliar del manzano; sin embargo, el uso de bioestimulantes, como compuesto, parece limitado. 